\title{
Factors Affecting Adolescents in Determining the Ideal Number of Children
}

\author{
Alya Rohma Indrastuti ${ }^{1}$, Lutfi Agus Salim ${ }^{2}$ \\ ${ }^{1}$ Bachelor Student in Faculty of Public Health, Universitas Airlangga, Surabaya, Indonesia, ${ }^{2}$ Associate Professor \\ in Department Biostatistics and Demography, Faculty of Public Health, Universitas Airlangga, Surabaya,
} Indonesia

\begin{abstract}
The preference of ideal number of children among adolescents can predict future fertility rates and population growth. This study aims to analyze the determinants of preference of ideal number of children in adolescents aged 15-24 years in Indonesia. The method used in this study is descriptive with data analysis of IDHS 2017. The results show that the preference of ideal number of children among adolescents in Indonesia is 2.7 children. This figure increase from the average preference of ideal number of children in 2012 and is higher than the 2015 Total Fertility Rate, which is 2.28. Factors that influence the preference of ideal number of children among adolescent are the characteristics and socio-demographic background, exposure to media, and the discussion on adolescent reproductive health.
\end{abstract}

Keywords: Preference of ideal number of children, Adolescents, Determinants of preference of ideal number of children.

\section{Introduction}

The total population of Indonesia is 237.6 million (2010 Population Census). This count has increased to 255.18 million people based on the 2015 Inter-Census Population Survey. Central Bureau of Statistics projects that the total population in Indonesia will increase until 2025. Currently, Indonesia is ranked fourth in the country with the most total population in the world. First place is China with 1,4 billiontotal population of the 7.8 billion total population in the world. Based on the Indonesian Population Projection for 2015-2045, the growth rate is $1.04 \%$. There are several components that affect population growth. These components include birth (fertility), death (mortality), and movement (migration). Total Fertility Rate (TFR) in 2020 is $2.1^{(1)}$.

Data from the Central Bureau of Statistics in 2019 shows that the number of adolescents (18-24 years old)

\section{Corresponding Author: \\ Lutfi Agus Salim}

Faculty of Public Health, Universitas Airlangga,

Surabaya

Email: lutfi.as@fkm.unair.ac.id in Indonesia is 44,209.8 million $^{(2)}$. Adolescence is a period of transition from children to adults. One of the things that marked this transition was starting a new life by forming a family. Starting a family life, of course, must be carefully planned by the adolescents. This planning cannot be separated from the desire to have children, including the preference for the number of children. Preference is a form of expressing feelings of preferring something. Preference has in common with closed behavior. Skinner (1938) in Notoadmodjo (2010) states that closed behavior occurs when the response to a stimulus cannot be clearly observed by others. The responses that appear are only limited to attention, perceptions, feelings, and attitudes. Therefore, the preference for the number of children in adolescents can be interpreted as a form of expression for the number of children they want to have. The preference for the ideal number of children desired can be used to predict future fertility rates ${ }^{(3)}$.

National Population and Family Planning (NPFP) introduced the Family Development, Population and Family Planning (Bangga Kencana) Program at the end of 2019 as a change in the name of the Population, Family Planning and Family Development (KKBPK) 
program. To realize that program, NPFP 2020-2024 Strategic Plan (Renstra) was used as a reference in program implementation. One of the strategic issues that must be considered in developing Renstra is the population structure. Indonesia has the opportunity to get a demographic bonus with the increasing proportion of the population of productive age in the demographic structure. This structure must be maximally utilized, one of which is by keeping the TFR at a certain level. Therefore, this study aims to analyze the determinants of preference for the number of children in adolescents aged 15-24 years with unmarried status in Indonesia.

\section{Method}

The research was used Indonesian Demographic and Health Survey (IDHS): Adolescent Reproductive Health in 2017. The research method used was descriptive. Data were collected by means of literature study and analyzed descriptively. The samples of this study were young men and women aged 15-24 with unmarried status in Indonesia. The number of samples was adjusted to the number of samples in the Adolescent Reproductive Health IDHS 2017, which was 22,583 people. As many as 12,612 boys and 9,971 girls.

\section{Result}

Preference for Ideal Number of Children in Adolescents: Based on data from the 2017 IDHS for Adolescent Reproductive Health, the average preference for the ideal number of children for both male and female adolescents in Indonesia is 2.7. This figure has increased from 2012. For male adolescents, the average preference for the ideal number of children has increased from 2.5 children to 2.7 children. Meanwhile, female adolescents increased from 2.3 to 2.7 children.
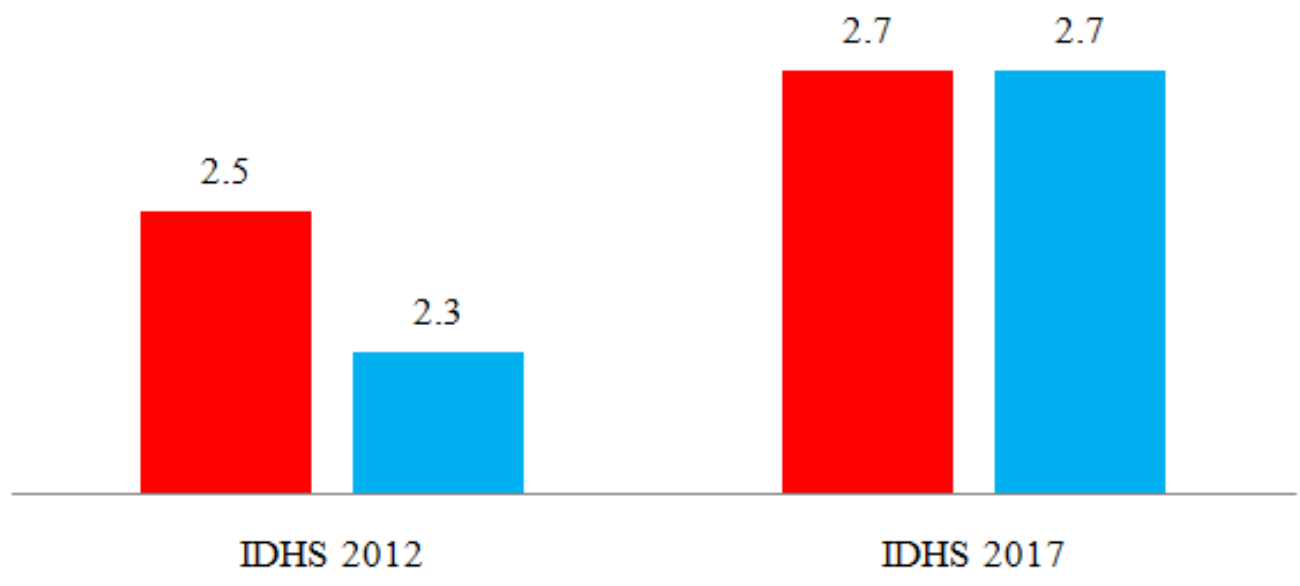

IDHS 2012

IDHS 2017

- Men Women

Figure 1. Average Preference of Ideal Number of Children by Adolescent in 2012 and 2017

Characteristics and Social Demographic Background of Adolescents: Based on data from the IDHS2017, the majority of adolescent respondents in Indonesia are 15-19 years old (64\%). In addition, the majority of respondents were male adolescents (56\%), the highest level of education was not graduating from high school $(50 \%)$, and mostly on highest economic status $(23 \%)$.

Table 1. Characteristics and Social Background of Adolescent

\begin{tabular}{|l|l|c|c|}
\hline Characteristics & Category & n & Percentage \\
\hline \multirow{2}{*}{ Sex } & Men & 12.612 & $56 \%$ \\
& Women & 9.971 & $44 \%$ \\
\hline \multirow{2}{*}{ Age } & $15-19$ & 14.463 & $64 \%$ \\
& $20-24$ & 8.120 & $36 \%$ \\
\hline
\end{tabular}




\begin{tabular}{|l|l|c|c|}
\hline Characteristics & Category & n & Percentage \\
\hline \multirow{5}{*}{ Residence } & Urban & 12.759 & $56 \%$ \\
& Rural & 9.824 & $44 \%$ \\
\hline \multirow{5}{*}{ Education } & No Education & 91 & $0,4 \%$ \\
& Incomplete Primary & 624 & $3 \%$ \\
& Complete Primary & 913 & $4 \%$ \\
& Incomplete Secondary & 11.354 & $50 \%$ \\
& Complete Secondary & 5.597 & $25 \%$ \\
& Higher & 4.005 & $17,6 \%$ \\
\hline \multirow{5}{*}{ Wealth Index } & Poorest & 3.723 & $17 \%$ \\
& Poorer & 4.320 & $19 \%$ \\
& Middle & 4.505 & $20 \%$ \\
& Richer & 4.779 & $21 \%$ \\
& Richest & 5.255 & $23 \%$ \\
\hline
\end{tabular}

Average ideal number of children is 2.8 children. Adolescent aged 20-24 years have a higher preference when compared to adolescents aged 15-19 years. Based on the level of education, the highest average preference for ideal number of children is owned by adolescents with a tertiary education level and not completing elementary school, both for male and female adolescents. The highest average preference for ideal number of children based on economic status is owned by male adolescents with the lowest economic status. While the average preference for the ideal number of children in urban and rural adolescents was not found to be different, as many as 2.7 children.

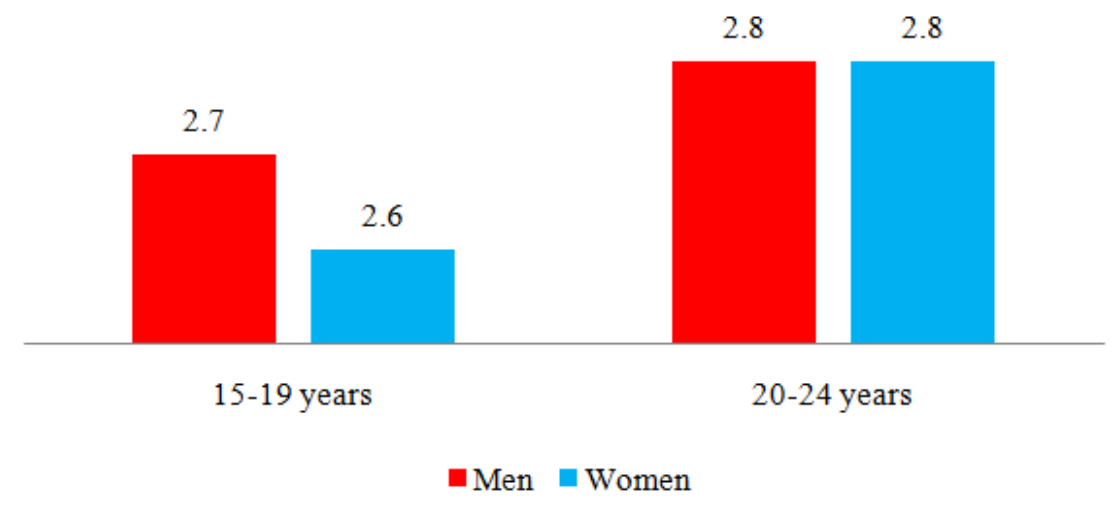

Figure 2. Preference of Ideal Number of Children in Adolescents Based on Age and Sex

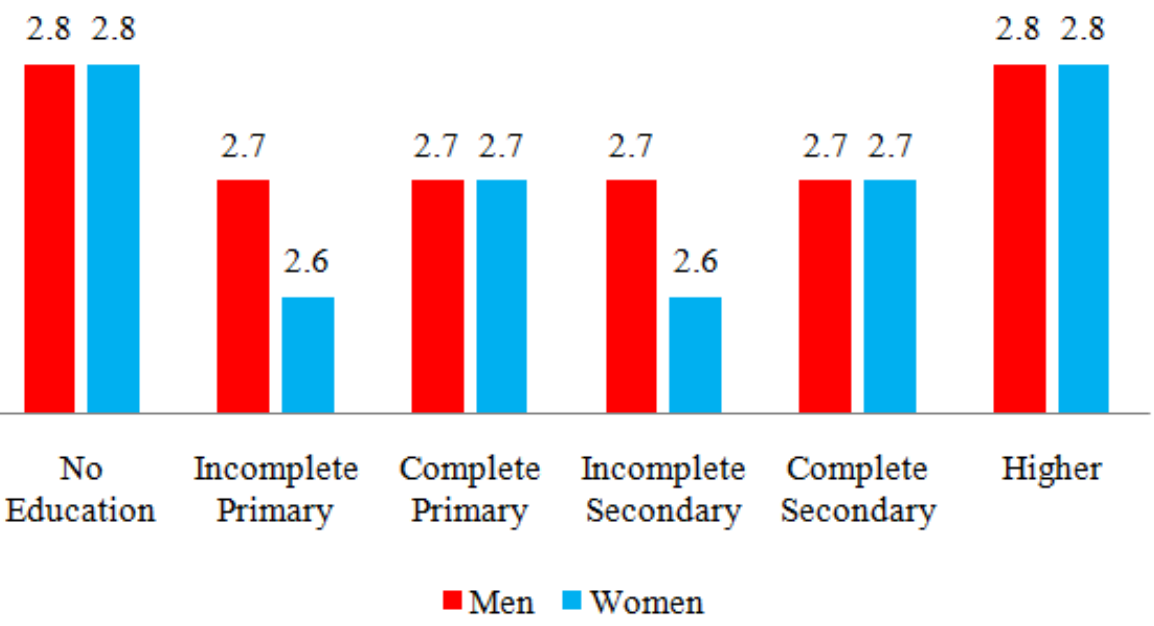

Figure 3. Preference for Ideal Number of Children in Adolescents Based on Education Level 


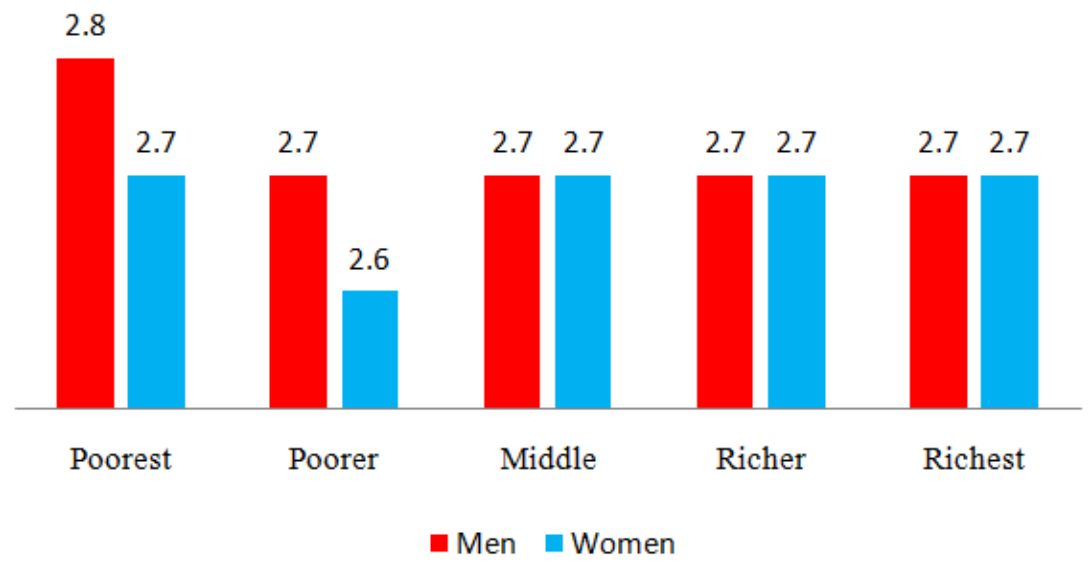

Figure 4. Preference for Ideal Number of Children in Adolescents Based on Economic Status

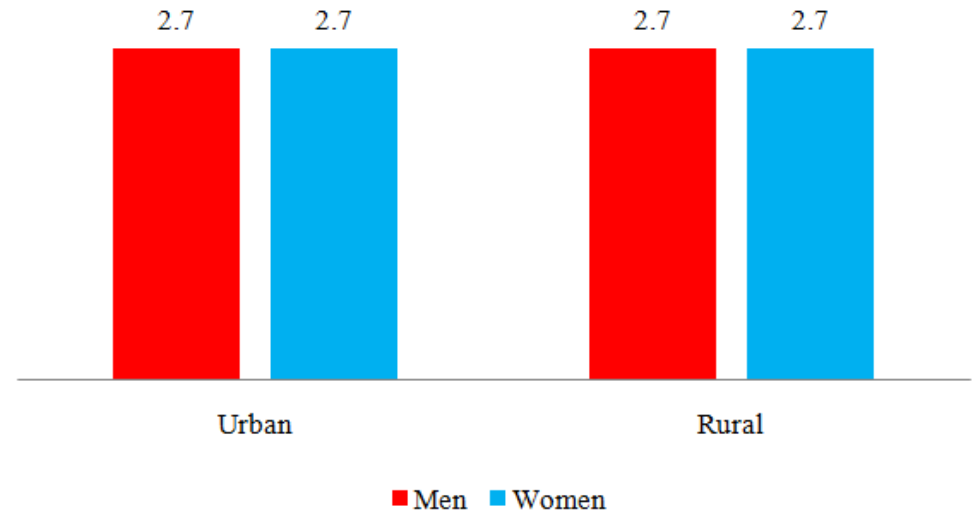

Figure 5. Preference for Ideal Number of Children in Adolescents by Residence

Mass Media Exposure: The most dominant mass media for obtaining information on reproductive health is television. At least in the last week, as many as $77 \%$ of young women watched television, $12 \%$ listened to the radio, and $11 \%$ read printed newspapers or magazines. Meanwhile, $73.1 \%$ of male adolescents watch television, $11.4 \%$ listen to the radio, and $10.4 \%$ read print media. In addition, the majority of young men and women also used the internet to get information about reproductive health during the last 12 months prior to the survey.

Percentage of male and female adolescents exposed to the three mass media has decreased when compared to 2012 and 2007. Boys who access the three mass media have decreased from $14 \%, 9 \%$, to $4 \%$. Likewise, the percentage of young women decreased from $13 \%, 8 \%$, to $4 \%$.

Youth Discussion About Reproductive Health: Most of adolescent men and women in Indonesia discuss reproductive health with friends. Respectively, 51.1\% of the total male respondents and $61.6 \%$ of female respondents discussed with friends. Adolescents also discuss reproductive health with teachers, mothers and fathers. For male adolescents, respectively $42 \%, 10.8 \%$, and $8.3 \%$ of the total male adolescent respondents. Meanwhile, female adolescents were respectively $47.1 \%, 53 \%$ and $4.3 \%$ of the total female respondents.

\section{Discussion}

Preference for Ideal Number of Children in Adolescents: The average preference for the ideal number of children based on the IDHS 2017 data for Adolescent Reproductive Health is 2.7 children, which is higher than the average preference in 2012, the 2015 TFR, and the 2020 TFR projection can be used to predict future fertility rates. This is because the preference for the ideal number of children in adolescents can determine the number of children they have in life ${ }^{(4)}$.

As with the definition of fertility according to demographics, fertility is more related to the number of children born alive. Fertility also influences the 
population growth rate in a positive way. This means that the higher the fertility rate, the higher the population growth rate ${ }^{(5)}$. In addition, with controlled fertility rates, Indonesia can take full advantage of the demographic bonus.

Preference for the ideal number of children to have depends on how one views the value of children. In adolescence, of course, it is still quite strange about this. However, that does not mean that teenagers cannot plan what family life will be like, including the number of children they want to have in the future. These decisions and plans are of course inseparable from the influence of various factors such as characteristics, mass media exposure, and discussions on reproductive health.

\section{Characteristics and Social Demographic} Background of Adolescents: Both male and female adolescents aged 20-24 years have a desire for more children than adolescents aged 10-19 years. Preference for the number of children desired by young women and men in the future. A more mature age encourages adolescents to think further about what kind of family they want to form, including the ideal number of children they want to have ${ }^{(6)}$.

In addition, education is also a factor that influences a person in planning the number of children he wants. The results showed that adolescents with incomplete primary and secondary education had a higher average preference for ideal number of children compared to other levels of education. A person's knowledge will increase along with the education taken. It also affects the mindset to be broader and more open. Teens with higher education are more likely to consider the number and limits of children they want to have. Even so, it does not rule out if adolescents with higher education want to have children in large numbers ${ }^{(7)}$.

Another factor that drives decisions in planning the number of children is economic. When viewed from an economic point of view, the number of children desired is closely related to the costs and benefits that are obtained from a child. Economic status and how a person perceives the value of children will influence the demand or desire for the number of children in the future. For some people or adolescents, children can be seen as workers. Children are considered as contributors to income for families with low economic levels so that the preference for the ideal number of children is higher compared to other economic statuses ${ }^{(8)}$.
There are differences in the value of children in underdeveloped communities (low economy) and advanced communities (high economy). Low economic society places more emphasis on the quantity or number of children they have. The number of children born can be a guarantee and bring many benefits to the family. One of them is increasing productivity and family income $^{(9)}$. The presence of children is considered to be able to help the family economy when parents are not productive so that their needs can still be met. Whereas for high economic communities, children are invested in quality ${ }^{(10)}$. Children who are born tend to be few but their growth and development are optimized. Starting from fulfilling nutrition, education and health with the hope that children can compete in the labor market. In addition, children are the successors of the offspring who will then carry the good name of the family ${ }^{(11)}$.

Based on the research results, it can be seen that the preference for the ideal number of children in urban and rural adolescents was not found to be different. Adolescents in urban and rural areas, of course, have different behavior patterns. However, this does not mean that the preferences for having children in the future will be significantly different. The exposure of adolescents to mass media which provides information about certain reproductive health can explain this.

Mass Media Exposure: Understanding of reproductive health is influenced by several factors, one of which is access to information ${ }^{(12)}$. The majority of adolescents get information about reproductive health through television channels. The results also showed that most teenagers had used the internet to get information. One of the information obtained is about family planning. Getting information about family planning can certainly influence adolescents in making plans for family life in the future. This includes deciding the ideal number of children they want to have.

Youth Discussion About Reproductive Health: Children are a natural thing for discussion among married people. However, discussing reproductive health issues and the number of children they want is certainly a foreign topic among adolescents. Adolescent tend to think more about present than planning about family life. This makes Adolescent think that the ideal number of children can be decided after marriage ${ }^{(13)}$.

The idea that the number of children does not need to be eliminated now certainly indicates that 
adolescents need to have further discussions about reproductive health. In the modern era, adolescents are more preoccupied with daily activities and activities related to academics or non-academics. The results showed that the majority of adolescents discussed reproductive health with friends. Listyaningsih and Sumini (2015) state that adolescent more discussion about introductions, friendships, and dating. Teens do not feel the need to discuss the problem of family size, including the number of children they will have ${ }^{(14)}$. This becomes a challenge in itself considering the rampant phenomenon of promiscuity. It is feared that teenagers cannot plan their own lives.

The role of discussion on reproductive health is very important to guide adolescents into a planning generation. Families, especially fathers and mothers, have a big role to play in providing knowledge about reproductive health in adolescents. Even though as many as $53 \%$ of young women discussed with their mothers about reproductive health, there was still a low number of discussions among boys. Likewise, the discussion rate for adolescents regarding reproductive health with fathers only reached $8.3 \%$ for male adolescents and $4.3 \%$ for female adolescents ${ }^{(15)}$.

For some parents, information regarding the number of children is not appropriate for adolescents, especially those aged 15-19 years. This condition can encourage adolescents to discuss with peers who have almost the same understanding. The values that are absorbed by adolescents from their families and the environment can influence their preferences for the number of children they want. Adolescents tend to wish to have the same number of children as their current family condition.

Apart from families, schools, including teachers, also have an important role in discussions about reproductive health for adolescents. Information about the number of children, children's grades, benefits and reasons for having children can be obtained at the secondary school level. Furthermore, this information can trigger teenagers to have further discussions with the people around them. Fertility preferences show adolescents with reproductive knowledge are more likely to choose the recommended number of children. Having discussions and interactions with parents, teachers and friends will increase adolescent knowledge and make adolescents trained to plan and make decisions regarding the ideal number of children they want to have $\mathrm{e}^{(4)}$.

\section{Conclusion}

The preference for the ideal number of children among adolescents (15-24 years) based on the IDHS data for Adolescent Reproductive Health is 2.7 children. This figure is an increase from the preference for the ideal number of children in 2012 and is higher than the Total Fertility Rate (TFR) in 2015 of 2.28 children. This will affect the fertility rate and have an impact on increasing population growth rates and demographic bonuses if not controlled properly.

The factors that influence the preference for the ideal number of children among adolescents are the characteristics and socio-demographic background of adolescents including age, education and economy. Another factor is exposure to mass media and youth discussions about reproductive health.

Conflict of Interest: The authors have no conflict of interest with the material presented in this paper

\section{Sources of Funding: None}

Ethical Clearance: None. My paper is an idea and policy analysis to solve population problems

\section{References}

1. Central beurau of statistics BAPPENAS, UNFPA. Proyeksi Penduduk Indonesia 2015-2045 Hasil SUPAS 2015. Gandewa Pramatya Arta. Jakarta, Indonesia; 2018.

2. Central Bureau of Statistics. Profil Penduduk Indonesia Hasil Supas 2015. Jakarta: Central Bureau of Statistics; 2016.

3. Notoatmodjo S. Konsep Perilaku Kesehatan Dalam: Promosi Kesehatan Teori \& Aplikasi edisi revisi. Jakarta: RinekaCipta. 2010;

4. Arsyad SS, Nurhayati S. Determinan Fertiltias Di Indonesia. Kependudukan Indonesia. 2017 Jan 20;11(1).

5. Ainy H, Nurrochmah S, Katmawanti S. Hubungan Antara Fertilitas, Mortalitas, Dan Migrasi Dengan Laju Pertumbuhan Penduduk. Preventia: The Indonesian Journal of Public Health. 2019;4(1).

6. Sari AA. Determinan preferensi jumlah anak pada remaja (15-24 tahun) di 10 Provinsi Penyangga (Analisis data SDKI 2012). Universitas Indonesia; 2015.

7. Becker GS, Tomes N. Child endowments and the 
quantity and quality of children. Journal of political Economy. 1976;84(4, Part 2):S143-62.

8. Schultz TP. Demand for children in low income countries. Handbook of population and family economics. 1997;1:349-430.

9. Easterlin RA. An economic framework for fertility analysis. Studies in family planning. 1975;6(3):5463.

10. Becker S, Fonseca-Becker F, Schenck-Yglesias C. Husbands' and wives' reports of women's decision-making power in Western Guatemala and their effects on preventive health behaviors. Social Science \& Medicine [Internet]. 2006;62(9):231326. Available from: http://www.sciencedirect.com/ science/article/pii/S0277953605005320

11. Becker GS, Lewis HG. On the Interaction between the Quantity and Quality of Children. Journal of political Economy. 1973;81(2, Part 2):S279-88.
12. Yuniarti S, Sukandar H, Susiarno H. Analisis faktor yang berhubungan dengan ferfilitas: Suatu kajian literatur. Universitas Padjajaran, Bandung Pustaka unpad ac id (diakses 04 Desember 2016). 2013;

13. Kennedy E, Gray N, Azzopardi P, Creati M. Adolescent fertility and family planning in East Asia and the Pacific: a review of DHS reports. Reproductive health. $2011 ; 8(1): 11$.

14. Listyaningsih U, Sumini S. Jumlah Anak Ideal Menurut Remaja Di Daerah Istimewa Yogyakarta. Populasi [Internet]. 2015 Nov 1; Available from: https://jurnal.ugm.ac.id/populasi/article/ view/15694

15. Khan M, Maqbool M, Hurrah M, Adesina M, Fekadu G. Awareness About Reproductive Health In Adolescents And Youth: A Review. Journal of Applied Pharmaceutical Sciences and Research. 2019 Sep 29;2:1-5. 